\title{
Prevalence and Factors Associated with Hepatitis B Virus Surface Antigen and Human Immunodeficiency Virus Antibodies in Chronic Hemodialysis Patients Followed-Up in Lomé, Togo
}

\author{
Mounerou Salou ${ }^{1,2}$, Kossi Akomola Sabi ${ }^{3}$, Amen Tevi ${ }^{3}$, Koumavi Ekouevi ${ }^{4}$, Sika Dossim², \\ Fiali Lack5, Maléwé Kolou5, Yaotsè Anoumou Dagnra1,5
}

\author{
${ }^{1}$ National Reference Centre for HIV, STIs and Viral Hepatitis of Togo, Lomé, Togo \\ ${ }^{2}$ Pharmaceutical Department, Health Sciences Faculty of University of Lomé, Lomé, Togo \\ ${ }^{3}$ Nephrology Ward, University Teaching Hospital, Sylvanus Olympio, Lomé, Togo \\ ${ }^{4}$ Public Health Department, Health Sciences Faculty of University of Lomé, Lomé, Togo \\ ${ }^{5}$ Basic Medical Sciences Department, Health Sciences Faculty of University of Lomé, Lomé, Togo \\ Email: ^mounerous@gmail.com, ^msalou@univ-lome.tg
}

How to cite this paper: Salou, M., Sabi, K.A., Tevi, A., Ekouevi, K., Dossim, S., Lack, F., Kolou, M. and Dagnra, Y.A. (2019) Prevalence and Factors Associated with Hepatitis B Virus Surface Antigen and Human Immunodeficiency Virus Antibodies in Chronic Hemodialysis Patients Followed-Up in Lomé, Togo. Open Journal of Medical Microbiology, 9, 16-27. https://doi.org/10.4236/ojmm.2019.91003

Received: January 25, 2019

Accepted: February 25, 2019

Published: February 28, 2019

Copyright $\odot 2019$ by author(s) and Scientific Research Publishing Inc. This work is licensed under the Creative Commons Attribution International License (CC BY 4.0).

http://creativecommons.org/licenses/by/4.0/ c) (7) Open Access

\begin{abstract}
Introduction: In haemodialysis patients, the risk of acquiring blood-borne viral infections is an important cause of the dialysis's process. Indeed, viral infections are quite common in chronic haemodialysis patients including those due to viral hepatitis B and HIV. Objective: Determine the prevalence of HIV infection and hepatitis B infection among chronic hemodialysis patients of Togo. Methods: A cross-sectional study was conducted in chronic hemodialysis patients of Togo from January $1^{\text {st }}$ to December $31^{\text {st }}$, 2016. Sociodemographic and clinical data were collected. Antigen HBs was screened by a rapid immunochromatographic test (SD BIOLINE ${ }^{\circledR} \mathrm{HBsAg}$ ), and HIV antibodies were detected using a combination of 2 rapid diagnostic test, SD BIOLINE $^{\circledR}$ HIV-1/2 (first step) and TRIDOT test (second step). Results: During the study period, 95 subjects were included. Patient's age was ranking from 13 to 80 years with a mean of 46.6 years. The sex-ratio (M/F) was 1.8 and a duration average of dialysis was 51.7 months. The aetiologies of the chronic endstage kidney failure were related respectively to a vascular renal disease for $42.1 \%$ of the patients, glomerular nephropaty for $34.74 \%$, interstitial nephropaty for $9.47 \%$ and hereditary for $3.16 \%$. For $10.53 \%$ of the patients, the initial renal disease remained indefinite. Prevalence of antigen HBs and HIV antibodies were respectively $10.5 \%$ and $7.4 \%$. The frequency of
\end{abstract}


co-infection HBV and HIV was $1.1 \%$. Conclusion: The rates of $\mathrm{HBV}$ infection and HIV infection remain high in chronic hemodialysis in Togo, somewhat which is linked to an endemic aspect of these two viruses in the country. The type of initial renal disease (glomerular) and the vascular way (the central catheters) established the risk factors for the HIV infection while for the infection of HVB no factor was incriminated.

\section{Keywords}

HIV, HBV Prevalence, Hemodialysis, Chronic Renal Insufficiency

\section{Introduction}

Chronic renal failure (CKD) is a real global public health problem due to the increase of its main risk factors, namely hypertension and diabetes. It is defined by the persistence for more than three months of a decrease in glomerular filtration rate $(\mathrm{GFR})<60 \mathrm{ml} / \mathrm{min} / 1.73 \mathrm{~m}^{2}$, or by a GFR $>60 \mathrm{ml} / \mathrm{min} / 1.73 \mathrm{~m}^{2}$ associated with one or more markers renal impairment [1].

In the terminal stage, $\mathrm{CKD}$ requires occasional hemodialysis, peritoneal dialysis or renal transplantation. These treatments are started as soon as the patient is terminally ill with CKD, since his life is then directly threatened. Periodic hemodialysis consists of an exchange through a semipermeable membrane between the substances dissolved in the patient's blood and a saline solution of electrolytic composition close to that of a patient normal plasma called dialysate [2]. Its usual rhythm is three sessions of four hours on average per week. This replacement technique allows survival but increases the risk of viral infections, especially those caused by hepatitis B and HIV viruses, on immunocompromised people that is really impaired [3]. In west Africa, data published for some countries in terms of prevalence of HBs antigen in general population were $6.7 \%$ in Senegal in 1998 [4] and 17.6\% in Côte d'Ivoire in 2010 [5]. Also, in Togo, studies have been conducted on the prevalence of hepatitis B infection in general population including in People Living with HIV by PATASSI et al. [6] in 2010 and by EKOUEVI et al. in 2017 [7] on the prevalence of hepatitis B and HIV among men who have sex with men (MSM) but no prevalence study has been done in hemodialysis patients. We aimed to fill this gap by conducting this study whose objectives were to determine the seroprevalence of Human Immunodeficience Virus (HIV) antibodies and Hepatitis B Virus (HBV) surface antigen HBs (AgHBs) in chronic hemodialysis patients in Togo.

\section{Patients and Methods}

\subsection{Study Sites and Patient Recruitment}

A cross-sectional study was carried out in Lomé, the capital city of Togo from January $1^{\text {st }}$ to December $31^{\text {st }}, 2016$. We included chronic hemodialysis patients 
recruited in 5 health care centres of Lomé namely University Teaching Hospital Sylvanus Olympio (CHU SO) in the public sector and clinic TAAMBA, clinic UNIDIAL, clinic LA REFERENCE and polyclinic SAINT JOSEPH in the private sector.

We did not define the sample size before, we included patients consecutively for one year. It was patient of all ages, irrespectively of the sex, who had been chronically treated by hemodialysis for more than 3 months and who were informed and gave their free consent were selected to participate into the study.

\subsection{Biological Analyses and Data Collection}

For each hemodialysis patient, we used avalidated questionnaire to record sociodemographic (marital status, date and place of birth, sex, ethnicity, occupation, area of provenance, level of education), clinical (type of initial nephropathy) and biological (results of HBV and HIV serological screening) data. Dialysis data were represented by the date of the first hemodialysis, the dialysis approach, previous or current blood transfusion received in dialysis. For each hemodialysis patient, $5 \mathrm{ml}$ of venous blood was collected in a dry tube under aseptic conditions using standard sampling equipment with disposable needles and syringes. The blood samples collected were sent to the national reference center for HIV, STIs and Viral hepatitis located at CHU SO to perform HIV and HBV serological screening. The detection of HBs antigen ( $\mathrm{HBsAg}$ ) was done by a rapid immunochromatographic test (SD BIOLINE ${ }^{\circledR} \mathrm{HBsAg}$ ). The detection of HIV antibodies was done regarding the national algorithm in use in the country. We used a combination of 2 rapid diagnostic test (RDT). The screening started by a sensitive RDT which is an immunochromatographic test (SD BIOLINE ${ }^{\circledR} \mathrm{HIV}-1 / 2$ ). All positive result was tested by a second very specific RDT such as TRI-DOT ${ }^{\circledR}$. When there was a discrepancy between the 2 results (i.e. second test was negative), we performed in third step a Western Blot $\left(\operatorname{Innolia}^{\circledR}\right)$ test for final decision.

\subsection{Statistical Analysis}

Statistical analysis was done on the R Studio version 3.3.2 software. Results were expressed as numbers and percentages for the qualitative variables or as medians for the quantitative variables. KHI 2 test and the Fisher's exact test were used to compare respectively percentages and averages. $\mathrm{P}$ value $<0.05$ was considered statistically significant.

A univariate and multivariate logistic regression was performed to investigate the associated factors. The explanatory variables were some socio-demographic, clinical variables. The variables statistically associated with HIV infection and HBV infection in the univariate analysis with a degree of significance $\mathrm{p}<0.20$ were introduced into the initial model. The top-down step-by-step procedure was used to select the final model. It consisted in including all the variables chosen in the initial model and then gradually removing the least significant variables. At each step, it was verified that there was no major confusion between the 
removed variable and those remaining in the model by checking for changes in their Odds ratio (tolerated variation: $20 \%$ ) or even radical changes in their degrees of significance. The multivariate analysis made it possible to estimate the Adjusted Coastline Ratio (RCa) and its confidence interval at 95\% for each variable selected. After obtaining the final model, interactions were sought between the different variables of the final model by including interaction terms (product of the 2 variables concerned) in the model and checking their non-significance. The adequacy of the model was checked on the basis of the $\mathrm{R}^{2}$ value.

\section{Results}

During one year, overall 95 patients were included. Study population characteristics are shown in Table 1 . The mean age was 46.6 years with extremes of 13 and 80 years. The sex ratio M/F was 1.8. Clinically, vascular nephropathy cases (40/95) was the predominant (42.1\%) initial nephropathy and in 10.5\% (10/95) of patients, the initial nephropathy remained indeterminate (Table 1). Dialysis made an by an arterio-venous fistula (AVF) as vascular access was found in 48 $(50.5 \%)$ and $49.5 \%(\mathrm{n}=47)$ had central venous catheters including $10.5 \%$ permanent catheters and $39.0 \%$ single catheters (Table 1). High blood pressure was the most common cause of kidney disease with $82.1 \%$ (78/95) of cases. The minimum duration of dialysis was 3 months and the maximum duration was 180 months. The average duration of dialysis was 51.7 months. Patients with a hemodialysis duration, less than 5 years accounted for 62.1\% (59/95) (Table 1).

Before the beginning of the screening, 1 (1.1\%) patient was recognized as HBsAg carrier and 4 (4.2\%) were identified as HIV infected people. All patients (100\%) have been transfused at least once since initiation of dialysis. Overall, amongst 95 kidney failure patients included, we found 10 (10.5\%) carrying HBsAg and 7 (7.4\%) were HIV infected. The prevalence of hepatitis B Virus, surface antigen ( $\mathrm{HBs} \mathrm{Ag}$ ) and Human Immunodeficiency Virus antibodies in chronic hemodialysis patients in Lomé, Togo was respectively $10.5 \%, \mathrm{CI}_{95 \%}[5.4 \%$ - 18.9\%] and 7.4\% (7/95), $\mathrm{CI}_{95 \%}$ [3.3\% - 15.1\%].

Only $1(1.1 \%)$ patient was found co-infected by HBV and HIV.

Upon HIV status, 63.6\% (55/88)o f HIV-negative patients and 71.4\% (5/7) of HIV-infected people were male, with no statistically significant difference ( $\mathrm{p}=$ 0.9999) (Table 1). Regarding age, 50.0\% (44/88) of HIV-negative patients and $57.1 \%$ (4/7) of HIV-positive patients were under 46 years, this difference was not statistically significant $(\mathrm{p}=0.9999)$ (Table 1$)$.

The risk of having an HIV infection is significantly higher for subjects with initial glomerular nephropathy than the others (18.18 vs $1.61, \mathrm{RCa}=22.06 ; \mathrm{CI}_{95 \%}$ $[2.97-481.23] \mathrm{p}$ value $=0.0098)($ Table 2$)$. In addition to that, the risk of being infected with HIV is significantly higher in patients using a single or permanent catheter $\left(12.77\right.$ vs $2.08, \mathrm{RCa}=10.69, \mathrm{CI}_{95 \%}[1.40-236.25]$, $\mathrm{p}$ value $\left.=0.0498\right)$ (Table 2).

Based on HBV surface antigen status, 63.5\% (54/85) of patients who did not 
Table 1. Characteristics of study population.

\begin{tabular}{|c|c|c|c|c|c|c|}
\hline & \multirow{2}{*}{$\begin{array}{c}\begin{array}{c}\text { Total } \\
(\mathrm{N}=95)\end{array} \\
\mathrm{N}\end{array}$} & \multicolumn{2}{|c|}{$\begin{array}{l}\text { VIH Negative } \\
\qquad(\mathrm{n}=88)\end{array}$} & \multicolumn{2}{|c|}{$\begin{array}{l}\text { VIH Positive } \\
\qquad(\mathrm{n}=7)\end{array}$} & \multirow[t]{2}{*}{$P$ value } \\
\hline & & $\mathrm{n}_{1}$ & $\%$ & $\mathrm{n}_{2}$ & $\%$ & \\
\hline Sex & 95 & & & & & $0.9999^{+}$ \\
\hline Female & & 32 & 36.36 & 2 & 27.57 & \\
\hline Male & & 56 & 63.64 & 5 & 71.43 & \\
\hline Vascular acces & 95 & & & & & $0.0954^{+}$ \\
\hline Permanent catheter & & 9 & 10.23 & 1 & 14.29 & \\
\hline Single catheter & & 32 & 36.36 & 5 & 71.42 & \\
\hline arterio-venous fistula (AVF) & & 47 & 53.41 & 1 & 14.29 & \\
\hline Initial nephropathy & 95 & & & & & $0.0307^{+}$ \\
\hline Glomerular & & 27 & 30.68 & 6 & 85.71 & \\
\hline Hereditary & & 3 & 3.41 & 0 & 0.00 & \\
\hline Indeterminate & & 10 & 11.36 & 0 & 0.00 & \\
\hline Interstitial & & 8 & 9.09 & 1 & 14.29 & \\
\hline Vascular & & 40 & 45.46 & 0 & 0.00 & \\
\hline High Blood pressure & 95 & & & & & $0.1059^{+}$ \\
\hline No & & 14 & 15.91 & 3 & 42.86 & \\
\hline Yes & & 74 & 84.09 & 4 & 57.14 & \\
\hline Diabetes & 95 & & & & & $0.9999^{+}$ \\
\hline No & & 77 & 87.50 & 6 & 85.71 & \\
\hline Yes & & 11 & 12.50 & 1 & 14.29 & \\
\hline Hepatitis B & 95 & & & & & $0.9999^{+}$ \\
\hline No & & 87 & 98.86 & 7 & 100.00 & \\
\hline Yes & & 1 & 1.14 & 0 & 0.00 & \\
\hline Median age (year) & 95 & & & & & $0.9999^{+}$ \\
\hline$<46$ & & 44 & 50.00 & 4 & 57.14 & \\
\hline$\geq 46$ & & 44 & 50.00 & 3 & 42.86 & \\
\hline Duration on hemodialysis(year) & 95 & & & & & $0.7059^{+}$ \\
\hline Duration $\leq 5$ & & 54 & 61.36 & 5 & 71.43 & \\
\hline Duration $>5$ & & 34 & 38.64 & 2 & 28.57 & \\
\hline
\end{tabular}

${ }^{+}$Fisher's exact test.

have and $70 \%(7 / 10)$ of carriers were male, with no statistically significant difference $(\mathrm{p}=0.9999)$ (Table 3). Concerning age, 51.8\% (44/85) of HBs Antigen-negative patients and $40.0 \%$ (4/10) of HBs Antigen positive patients were under 46 years of age; this difference was not statistically significant $(\mathrm{p}=0.9999)$ (Table 3). No variables were associated with hepatitis B virus surface antigenpresence (Table 4). 
Table 2. Factors associated to HIV infection in multivariate analysi.

\begin{tabular}{cccccccc}
\hline & \multicolumn{5}{c}{ Initial model } & \multicolumn{3}{c}{ Final model } \\
\hline & $\mathrm{n} / \mathrm{N}$ & $\mathrm{RC}$ & $\mathrm{CI} 95 \%$ & $\mathrm{P}$ value & $\mathrm{RC}_{\mathrm{a}}$ & $\mathrm{CI} 95 \%$ & $\mathrm{P}$ value \\
\hline $\begin{array}{c}\text { Occupation } \\
\text { Private }\end{array}$ & $2 / 54$ & 1 & & 0.0583 & & & 0.0500 \\
Public sector & $5 / 41$ & 6.86 & {$[1.07-66.20]$} & & 7.08 & {$[1.13-67.62]$} & \\
Vascular access & & & & 0.0569 & & & $0.0498^{* *}$ \\
AVF & $1 / 48$ & 1 & & & 1 & & \\
Simple/Permanent catheter & $6 / 47$ & 10.20 & {$[1.30-228.65]$} & & 10.69 & {$[1.40-236.25]$} & \\
Initial nephropathy & & & & 0.0130 & & & $0.0098^{* *}$ \\
others & $1 / 62$ & 1 & & & 1 & & \\
Glomerular & $6 / 33$ & 20.68 & {$[2.63-464.17]$} & & 22.06 & {$[2.97-481.23]$} & \\
High blood pressure & & & & 0.7935 & & & \\
No & $4 / 78$ & 1 & & & & & \\
yes & $3 / 17$ & 1.29 & {$[0.16-8.46]$} & & & & \\
\hline
\end{tabular}

${ }^{+}$Fisher's exact test. ${ }^{* *} \mathrm{p}$ value is significant.

Table 3. Comparative table of chronic hemodialysis subjects carrying HBsAgverus those not infected with HBV.

\begin{tabular}{|c|c|c|c|c|c|c|}
\hline & \multirow{2}{*}{$\begin{array}{c}\begin{array}{c}\text { Total } \\
(\mathrm{n}=95)\end{array} \\
\mathrm{N}\end{array}$} & \multicolumn{2}{|c|}{$\begin{array}{l}\text { HBV Negative } \\
\qquad(\mathrm{n}=85)\end{array}$} & \multicolumn{2}{|c|}{$\begin{array}{l}\text { HBV Positive } \\
\qquad(\mathrm{n}=10)\end{array}$} & \multirow[t]{2}{*}{$P$ value } \\
\hline & & $\mathrm{n}_{1}$ & $\%$ & $\mathrm{n}_{2}$ & $\%$ & \\
\hline Sex & 95 & & & & & $0.9999^{+}$ \\
\hline Female & & 31 & 36.47 & 3 & 30.00 & \\
\hline Male & & 54 & 63.53 & 7 & 70.00 & \\
\hline Vascular access & 95 & & & & & $0.3341^{+}$ \\
\hline Permanent catheter & & 10 & 11.76 & 0 & 0.00 & \\
\hline Single catheter & & 31 & 36.47 & 6 & 60.00 & \\
\hline AVF & & 44 & 51.76 & 4 & 40.00 & \\
\hline Initial nephropathy & 95 & & & & & $0.8626^{+}$ \\
\hline Glomerular & & 28 & 32.94 & 5 & 50.00 & \\
\hline Hereditary & & 3 & 3.53 & 0 & 0.00 & \\
\hline Indeterminate & & 9 & 10.59 & 1 & 10.00 & \\
\hline Interstitial & & 8 & 9.41 & 1 & 10.00 & \\
\hline Vascular & & 37 & 43.53 & 3 & 30.00 & \\
\hline high blood pressure & 95 & & & & & $0.9999^{+}$ \\
\hline No & & 15 & 17.65 & 2 & 20.00 & \\
\hline Yes & & 70 & 82.35 & 8 & 80.00 & \\
\hline Diabetes & 95 & & & & & $0.1113^{+}$ \\
\hline No & & 76 & 89.41 & 7 & 70.00 & \\
\hline Yes & & 9 & 10.59 & 3 & 30.00 & \\
\hline Median age (year) & 95 & & & & & $0.5235^{+}$ \\
\hline
\end{tabular}




\section{Continued}

\begin{tabular}{|c|c|c|c|c|c|c|}
\hline$<46$ & & 44 & 51.77 & 4 & 40.00 & \\
\hline$\geq 46$ & & 41 & 48.23 & 6 & 60.00 & \\
\hline Time duration on hemodialysis (year) & 95 & & & & & $0.3095^{+}$ \\
\hline$\leq 5$ & & 51 & 60.00 & 8 & 80.00 & \\
\hline$>5$ & & 34 & 40.00 & 2 & 20.00 & \\
\hline
\end{tabular}

${ }^{+}$Fisher's exact test.

Table 4. Investigation of factors associated with HBV infection in chronic hemodialysis patients in univariate analysis.

\begin{tabular}{|c|c|c|c|c|c|}
\hline Parameters & $\mathrm{n} / \mathrm{N}$ & $\%$ & RC & CI95\% & $P$ values \\
\hline Sex & & & & & 0.6872 \\
\hline Female & $3 / 34$ & 8.82 & 1 & & \\
\hline Male & $7 / 61$ & 11.48 & 1.34 & {$[0.35-6.56]$} & \\
\hline Marital status & & & & & 0.6525 \\
\hline married, widowed & $7 / 72$ & 9.72 & 1 & & \\
\hline unmarried & $3 / 23$ & 13.04 & 1.39 & {$[0.28-5.54]$} & \\
\hline Occupation & & & & & 0.3805 \\
\hline Privatesector & $7 / 54$ & 12.96 & 1 & & \\
\hline Public sector & $3 / 41$ & 7.32 & 0.53 & {$[0.11-2.05]$} & \\
\hline Region of origin & & & & & 0.3531 \\
\hline Maritime & $7 / 77$ & 9.09 & 1 & & \\
\hline others & $3 / 18$ & 16.67 & 2.00 & {$[0.40-8.15]$} & \\
\hline \multicolumn{6}{|l|}{ Nationality } \\
\hline Togolese & $10 / 91$ & 10.99 & & & \\
\hline Others & $0 / 4$ & 0.00 & & & \\
\hline Vascular access & & & & & 0.4845 \\
\hline AVF & $4 / 48$ & 8.33 & 1 & & \\
\hline Simple/Permanent catheter & $6 / 47$ & 12.77 & 1.61 & {$[0.43-6.68]$} & \\
\hline Initial nephropathy & & & & & 0.2910 \\
\hline Others & $5 / 62$ & 8.07 & 1 & & \\
\hline Glomerular & $5 / 33$ & 15.15 & 2.04 & {$[0.53-7.89]$} & \\
\hline High blood pressure & & & & & 0.8544 \\
\hline Yes & $8 / 78$ & 10.26 & 1 & & \\
\hline No & $2 / 17$ & 11.77 & 1.17 & {$[0.17-5.26]$} & \\
\hline Diabetes & & & & & 0.0969 \\
\hline No & $7 / 83$ & 8.43 & 1 & & \\
\hline Yes & $3 / 12$ & 25.00 & 3.62 & {$[0.69-15.82]$} & \\
\hline Median age (year) & & & & & 0.4845 \\
\hline
\end{tabular}


Continued

\begin{tabular}{cccccc}
\hline$>46$ & $6 / 47$ & 12.77 & 1 & & \\
$\leq 46$ & $4 / 48$ & 8.33 & 0.62 & {$[0.15-2.33]$} & \\
Time duration on hemodialysis (year) & & & & & 0.2322 \\
$>5$ & $2 / 36$ & 5.56 & 1 & & \\
$\leq 5$ & $8 / 59$ & 13.56 & 2.67 & {$[0.62-18.39]$} & \\
\hline
\end{tabular}

\section{Discussion}

Togo is a country located in west Africa with around 7 million inhabitants. We aimed to estimate the rate of subjects infected either by HIV or HBV or both 2 viruses in chronic hemodialysis patients. We also searched for potential risk factor to acquire these two viruses for this target population. We found $10.5 \%$ as seroprevalence rate of HBsAg and no related factors for HBV infection's acquisition. We estimated the prevalence of HIV infection at $7.4 \%$. Furthermore, despite the low number of positive cases, initial glomerular nephropathy and single or permanent catheter as vascular access for dialysis were risks factor to acquire HIV infection for chronic hemodialysis patients in our settings.

Prevalence of HBsAg that we found, is in line with togolese general population's rate [6]. According to World Health Organization (WHO), Togo and others countries of west Africa are endemic areas of Hepatitis B infection where rates of hepatitis B infection are ranking from $8 \%$ to $15 \%$ [6] [7]. In Togo, prevalence of HBV infection increases from south to north with higher rates, unfortunately, we did not check for origin of patients. Others studies of HBsAg's prevalence around the world, among hemodialysis patients, reported rates ranging from $1.2 \%$ to $17.6 \%$. Thus, in Asia, data are lower than what we observed. In Iran [8], in Lebanon [9], in Japan [10] and in India [11], authors reported respectively 1.2\%, 1.2\%. 2.6\%, 3.2\%. In Africa, from Morocco, BOULAAJAJ et al. [12] found a seroprevalence of $2 \%$ upon 199 hemodialysis patients while EL YOUBI et al. [13] in 2008, reported $12.2 \%$ from 90 patients. From sub-Saharan countries, HALLE et al. [14] reported 6\% in Cameroon in 2016 based on 86 chronic hemodialysis patients. In Ivory Coast, area closed to Togo, KOUASSI-M'BENGUE et al. [5] reported a rate of $17.6 \%$ in 2010 . This variation in prevalence may be linked to the endemic areas of HBV and may also be related to the degree of compliance with the universal precautions for the prevention of nosocomial infections in hemodialysis patients. In Togo, no provision for vaccination of chronic renal failure patients is made before the dialysis stage; this is because most of them are already in the terminal stage with the need for dialysis.

Our study did not identify any risk factor for acquire HVB. None of these following parameters age, sex, type of initial nephropathy, vascular approach, the concept of blood transfusion and duration of dialysis was not statistically significant ( $p>0.5$ ) in hemodialysis patients with HBsAg positive compared to seronegative HBsAg patients. This result is similar to those of LUMA et al. [15] in Cameroon and KOUASSI-M'BENGUE et al. [5] in Côte d'Ivoire. With regard 
to blood transfusion, it should be pointed out that this is one of the essential adjuvant therapeutic components in the management of hemodialysis in Togo. Which could have constituted a selection bias. However, PRAKASH et al. [11] demonstrated in their study that the number of blood transfusion bags $(>10)$ was major risk factor for acquisition of viral hepatitis $\mathrm{B}$ and $\mathrm{C}$ with $\mathrm{p}<0.05$.

Than that of the adult population in Africa estimated 6.1\% [4], that of pregnant women in Morocco in 2015 which was 2.3\% [16] this could be justified by the fact that hemodialysis is a population at risk. The risk is multifunctional on the one hand, the immunodepression linked to chronic renal disease aggravated by the inactivity or the ineffectiveness recognized of the vaccination against hepatitis B on this ground; on the other hand, by the regular use of transfusion in chronic hemodialysis.

Regarding the prevalence of HIV infection, in the whole population aged 15 to 49 in Togo, it was $2.5 \%$. But this prevalence was predominantly female with $3.1 \%$ among women and $1.7 \%$ among men [17]. In our study, the prevalence of HIV infection in hemodialysis was estimated at $7.4 \%$, while in Abidjan it was twice ours (14.8\%) [5]. Several studies have shown very low prevalence or none HIV infection in hemodialysis patients. EL YOUBI et al. [13] BOULAAJAJ et al. [12], ZAHEDI et al. [18] noted zero prevalence. In India, MITTAL et al. [19] reported a low frequency of $1.7 \%$ but HALLE et al. [14] found a rate of $9.1 \%$ in Cameroon. These low prevalences could be explained by the implementation in these low-endemic countries of effective prevention strategies for the control of viral infections transmitted by blood transfusion. Given similar patterns of transmission of hepatitis B Virus and HIV infection, co-infections exist in areas of high endemicity for both viruses. In this study, HIV/HBV coinfections accounted for $1.1 \%$. KOUASSI-M'BENGUE et al. [5] reported a rate of $1.4 \%$. In a study of HIV-infected patients treated with antiretrovirals, however, PATASSI et al. found a prevalence of $10 \%$ of HIV/HBV coinfections in people living with HIV [6]. These high rates of HIV seroprevalence in some dialysis centers like ours would be related to the high prevalence of HIV-associated nephropathy or to multiple transfusions still used as a means of fighting anaemia in chronic renal failure. The type of initial nephropathy and the vascular approach were the risk factors associated with HIV infection in our study, so the risk of having HIV infection was significantly higher for subjects with initial glomerular nephropathy. than other nephropathies $(p=0.0098)$; furthermore, the risk of being infected with HIV was significantly higher in patients using a central venous catheter than a AVF ( $p=0.0498)$. This could be explained by the fact that HIV infection is one of the main causes of glomerular nephropathy; and our study population was young and therefore at risk of HIV infection. Central catheters are more exposed to infections than AVF [20]. In contrastKOUASSI-M'BENGUE et al. found no statistical link between the different frequencies and risk factors identified for HIV infection [5].

This study has some limitations. Indeed, we did not estimate the size of the 
study population. This could have an impact on prevalences we estimated and risks factors we investigated. Moreover, we did not investigate cases of occult hepatitis B by molecular biology. This could constitute a bias in estimating the prevalence of HBV-infected subjects.

\section{Conclusion}

Hemodialysis, a commonly used extrarenal treatment technique, allows prolonged survival of patients with chronic renal failure who have reached the end stage. However, it induces many mainly infectious complications in these patients. Furthermore, our study showed that some of this specific population were HBV or HIV infected respectively $10.5 \%$ and $7.4 \%$. The prevalence of these infections remains high in these patients compared to the general population. No risk factors were found for HBV infection, but glomerular nephropathy and central venous catheter were the risk factors for HIV infection in these patients. Finally, the risk of hospital acquired infection in chronic hemodialysis patients caused these 2 viruses would not be zero in our current hemodialysis practice.

\section{Acknowledgements}

We thank all chronic hemodialysis patients and all the centres of hemodialysis in Lomé.

Our heartfelt thanks to the distributor of the SDBioline ${ }^{\circledR}$ reagent brand in Togo.

We would like to thank also the nephrology ward team and the lab team (CNR VIH/IST) of Sylvanus Olympio teaching hospital of Lomé, Togo.

\section{Conflicts of Interest}

The authors declare no conflict of interest.

\section{References}

[1] National Kidney Foundation (2002) K/DOQI Clinical Practice Guidelines for Chronic Kidney Disease: Evaluation, Classification, and Stratification. American Journal of Kidney Diseases, 39, S1-S266.

[2] Rognant, N. and Laville, M. (2011) Prise en charge médicale de la lithiase urinaire. 17, 103-112.

[3] Chaabane, N.B., Loghmari, H., Melki, W., Hellara, O., Safer, L., Bdioui, F., et al. (2008) Chronic Viral Hepatitis and Kidney Failure. La Presse Médicale, 37, 665-678.

[4] Seck, A. (1998) Prévalence des virus B et C de l'Hépatiteenhémodialysechronique à Dakar. Thèse de doctorat, Université Cheikh Anta Diop, Sénégal, 37 p.

[5] Kouassi-M’bengue, A., Cissé, B., N'gnoh Ouattara, D., Doumbia, M., Yao, H. and Gnonsahé, D.A. (2013) Fréquences de l'hépatite virale B et duVIH chez les hémodialysés à Abidjan en 2010 Revue Bio-Africa. 11, 43-48.

[6] Patassi, A.A., Kotosso, A., Salou, M., Bawe, L.D., Krivine, A., Ephrem, M., et al. (2015) Prévalence des marqueurs du virus de l'hépatite B chez les patients infectés par le VIH et traités par anti-rétroviraux dans un pays a ressources limitées. 17, 655 p. 
[7] Ekouevi, K., Gbeasor-Komlanvi, F., Salou, M., Sewu, E., Blatome, T. and Dagnra, A. (2018) Prevalence and Factors Associated with Syphilis, HIV and Hepatitis B Virus Infections among Men Who Have Sex with Men in Togo in 2017. Revue dépidémiologie et de Santé Publique, 66, S280.

[8] Kalantari, H., Ebadi, S., Yaran, M., Maracy, M.R. and Shahshahan, Z. (2014) Prevalence and Risk Factors of Hepatitis B and C Viruses among Hemodialysis Patients in Isfahan, Iran. Advanced Biomedical Research, 3, 73. https://doi.org/10.4103/2277-9175.125869

[9] Abou Rached, A., El Khoury, L., El Imad, T., Geara, A.S., Jreijiry, J. and Ammar, W. (2016) Incidence and Prevalence of Hepatitis B and Hepatitis C Viruses in Hemodialysis Patients in Lebanon. World Journal of Nephrology, 5, 101-107. https://doi.org/10.5527/wjn.v5.i1.101

[10] Katayama, K., Sato, T., Do, S.H., Yamada, H., Tabuchi, A., Komiya, Y., et al. (2015) Hepatitis B Virus Infection in Hemodialysis Patients in Japan: Prevalence, Incidence and Occult Hepatitis B Virus Infection. Hepatology Research, 45, 1211-1219. https://doi.org/10.1111/hepr.12492

[11] Prakash, S., Jain, A., Sankhwar, S.N., Usman, K., Prasad, N., Saha, D., et al. (2014) Prevalence of Hepatitis B \& C Viruses among Patients on Hemodialysis in Lucknow, Uttar Pradesh. Clinical Epidemiology and Global Health, 2, 19-23. https://doi.org/10.1016/j.cegh.2013.03.001

[12] Boulaajaj, K., Elomari, Y., Elmaliki, B., Madkouri, B., Zaid, D. and Benchemsi, N. (2005) Infections virales: VHC, VHB et VIH chez les hémodialysés, CHU IbnRochd, Casablanca. Néphrologie \& Thérapeutique, 527, 271.

[13] El Youbi, R., Maaroufi, C., Benzakour, K., Arrayhani, M. and Sqalli Houssaini, T. (2009) Infections virales chez l'hémodialysé chronique. Revue d'Épidémiologie et de Santé Publique, 57, 25.

[14] Hallem, P., Ngo Boumssos, L., Folefack, K.F., Fouda, H., Ashuntantang, G. and Luma, H.N. (2016) Incidence de la séroconversion de l'hépatite virale B et du VIH chez les hémodialysés chroniques à Douala, Cameroun. Néphrologie \& Thérapeutique, 4933, 259.

[15] Luma, H.N., Halle, M.P., Eloumou, S.A.F.B., Azingala, F., Kamdem, F., DonfackSontsa and Ashuntantang, G. (2017) Seroprevalence of Human Immunodeficiency Virus, Hepatitis B and C Viruses among Haemodialysis Patients in Two Newly Opened Centres in Cameroon. Pan African Medical Journal, 27, 235. https://doi.org/10.11604/pamj.2017.27.235.13121

[16] Sbiti, M., Khalki, H., Benbella, I. and Louzi, L. (2016) Séroprévalence de l'AgHBs chez la femme enceinte dans le centre du Maroc. Pan African Medical Journal, 24, 187. https://doi.org/10.11604/pamj.2016.24.187.9849

[17] Rapport Annuel 2016 des activités du PNLS/IST-TOGO. Conseil National de Lutte contre le SIDA et les Infections Sexuellement Transmissibles. http://www.pnls.tg/rapports/RAPPORT\%20ANNUEL\%20PNLS\%202016.pdf

[18] Zahedi, M.J., Darvish Moghaddam, S., Alavian, S.M. and Dalili, M. (2012) Seroprevalence of Hepatitis Viruses B, C, D and HIV Infection among Hemodialysis Patients in Kerman Province, South-East Iran. Hepatitis Monthly, 12, 339-343. https://doi.org/10.5812/hepatmon.5969

[19] Mittal, G., Gupta, P., Thakuria, B., Mukhiya, G.K. and Mittal, M. (2013) Profile of Hepatitis B Virus, Hepatitis C Virus, Hepatitis D Virus and Human Immunodeficiency Virus Infections in Hemodialysis Patients of a Tertiary Care Hospital in Uttarakhand. Journal of Clinical and Experimental Hepatology, 3, 24-28. 
https://doi.org/10.1016/j.jceh.2013.02.003

[20] Ravani, P., Palmer, S.C., Oliver, M.J., Quinn, R.R., Macrae, J.M., Tai, D.J., et al. (2013) Associations between Hemodialysis Access Type and Clinical Outcomes: A Systematic Review. American Society of Nephrology, 24, 465-473.

https://doi.org/10.1681/ASN.2012070643 